\title{
Plasma somatomedin activity in protein calorie malnutrition
}

\author{
P. S. MOHAN AND KAMALA S. JAYA RAO
}

National Institute of Nutrition, Indian Council of Medical Research, Hyderabad

SUMMARY Somatomedin activity was assayed in the plasma of children suffering from protein calorie malnutrition by a bioassay using rat cartilage and expressed as sulphate uptake ratio. The sulphate uptake ratio was particularly reduced in kwashiorkor. In marasmus there was a slight reduction and the levels were still in the normal range. Plasma growth hormone (GH) levels were raised in kwashiorkor but were in the normal range in marasmus. Reduction in sulphate uptake ratio was observed only when plasma albumin levels were less than $2.5 \mathrm{~g} / 100 \mathrm{ml}(25 \mathrm{~g} / \mathrm{l})$. A rise in plasma GH was also observed but only below this threshold level.

Some of the actions of growth hormone (GH) on cartilage are believed to be mediated through GHdependent serum factors-the somatomedins (Daughaday, 1971). The liver is one of the known sites of somatomedin generation that has been shown to be stimulated by GH (McConaghey, 1972).

Raised GH levels have been observed in kwashiorkor (Raghuramulu and Jaya Rao, 1974), a condition in which the concentrations of various proteins synthesised in the liver, including albumin, are markedly decreased. A lowered level of serum somatomedin may act as a feedback to stimulate excess production of $\mathrm{GH}$ in this condition. Plasma somatomedin is generally measured by bioassays, in which the uptake of either $\mathrm{Na}_{2}{ }^{35} \mathrm{SO}_{4}$ or ${ }^{3} \mathrm{H}$-thymidine by cartilage in the presence of serum is determined. To test whether any correlation exists between plasma GH levels and somatomedin activity in protein calorie malnutrition, the ability of serum from children suffering from such malnutrition to stimulate $\mathrm{Na}_{2}{ }^{35} \mathrm{SO}_{4}$ uptake by rat cartilage was studied.

\section{Patients and methods}

Eight children suffering from kwashiorkor and 7 marasmic children were studied. They conformed to descriptions given earlier (Raghuramulu and Jaya Rao, 1974). Investigations were carried out immediately on admission to hospital and after 3 or 4 weeks

National Institute of Nutrition, Indian Council of Medical Research, Hyderabad

P. S. MOHAN, research assistant

KAMALA S. JAYA RAO, deputy director of nutritional rehabilitation on diets which provided $200 \mathrm{kcal}(0.836 \mathrm{MJ})$ and $4 \mathrm{~g}$ protein $/ \mathrm{kg}$ daily. A sample of venous blood was obtained after an overnight fast, under resting conditions. Blood was collected under heparin, plasma separated, and stored at $-20^{\circ} \mathrm{C}$.

The bioassay was carried out as described by Yde (1968) using 21-27 day-old male albino rats, fasted for 48 hours before the assay. The cartilage pieces were however not subjected to acid hydrolysis but digested with papain (Alford et al., 1972). The radioactivity in the hydrolysate was measured in a Packard liquid scintillation counter, using Bray's scintillating solution.

The assay was carried out by a symmetrical 4point bioassay using both reference (pooled plasma from healthy adults) and test plasma at 10\% (0.07 $\mathrm{ml})$ and $20 \%(0.14 \mathrm{ml})$ of the total incubation volume $(0.7 \mathrm{ml})$. Each concentration of the plasma was assayed in triplicate. Radioactivity was expressed per mg dry weight of the cartilage. The ratio of the radioactivity obtained with the test plasma to that obtained with the reference plasma was calculated and the average of the 6 observations was taken as the sulphate uptake ratio. Plasma samples of each child obtained on admission and after nutritional rehabilitation were assayed simultaneously, using the same rat to minimise interanimal variations.

In 7 independent assays normal plasma was used at $0,2 \cdot 5,5,7 \cdot 5,10,12 \cdot 5,15,17 \cdot 5,20 \% \mathrm{v} / \mathrm{v}$ concentrations and log dose response curves were constructed. The relationship was found to be linear up to a concentration of $20 \% \mathrm{v} / \mathrm{v}$ and the index of precision $(\lambda)$ was $0 \cdot 18 \pm 0 \cdot 020$ (mean \pm SE).

Plasma GH was estimated by the double antibody 
technique of Pennisi (1968), the materials used being similar to those described earlier (Raghuramulu and Jaya Rao, 1974). Plasma albumin was estimated by the biuret method (Wolfson et al., 1948).

\section{Results}

The results of the study are presented in the Table. The mean sulphate uptake ratio in children suffering from kwashiorkor was significantly lower than that observed in normal children $(P<0.001)$ and the values rose significantly after nutritional rehabilitation $(P<0.01)$. The mean value in marasmic children was not different from that observed in normal children. However, there was a slight but significant increase after treatment $(P<0.05)$.

The mean basal plasma GH level in children suffering from kwashiorkor was significantly higher than that observed in normal children $(P<0.01)$. The levels came down significantly after nutritional rehabilitation $(P<0 \cdot 05)$. The mean level in marasmic children was not different from that observed in normal children and there was no change after treatment.

Correlations were tested between sulphate uptake ratio and plasma $\mathrm{GH}$, between sulphate uptake ratio and plasma albumin, and between plasma $\mathrm{GH}$ and plasma albumin; both groups of children were tested separately before and after treatment. No positive correlations were obtained in any of the groups when tested individually. As the coefficients of correlation for both groups, before and after treatment, were not significantly different the entire data were combined for analysis. A significant correlation was obtained only between sulphate uptake ratio and plasma albumin concentration $(r=0.576, P<0.001$, Figure)

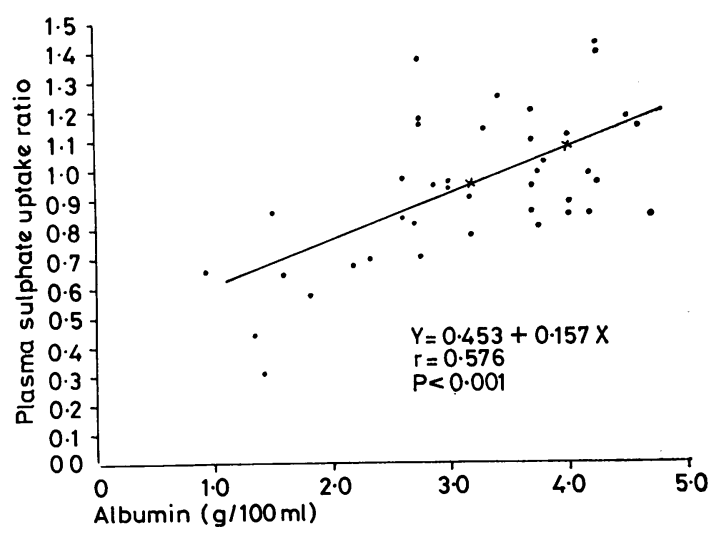

Figure Relationship between plasma sulphate uptake ratio and plasma albumin level.
Table Plasma sulphate uptake ratio and $G H$ levels in protein calorie malnutrition

\begin{tabular}{|c|c|c|}
\hline & $\begin{array}{l}\text { Sulphate uptake } \\
\text { ratio }\end{array}$ & $G H(n g / m l)$ \\
\hline $\begin{array}{l}\text { Normal children } \\
(n=11) \\
\text { Kwashiorkor }(n=8)\end{array}$ & $1.06 \pm 0.072$ & $8 \cdot 4 \pm 1 \cdot 83$ \\
\hline $\begin{array}{c}\text { Before treatment } \\
\text { After treatment } \\
\text { Marasmus }(n=7)\end{array}$ & $\begin{array}{l}0.61 \pm 0.059 \ddagger \\
0.97 \pm 0.085^{* *}\end{array}$ & $\begin{array}{r}30 \cdot 8 \pm 8 \cdot 29 ! \\
6 \cdot 8 \pm 2 \cdot 18^{*}\end{array}$ \\
\hline $\begin{array}{l}\text { Before treatment } \\
\text { After treatment }\end{array}$ & $\begin{array}{l}0.97 \pm 0.057 \\
1.09 \pm 0.056^{*}\end{array}$ & $\begin{array}{l}5.2 \pm 0.82 \\
3.9 \pm 1.06\end{array}$ \\
\hline
\end{tabular}

Before treatment $v$, after treatment

$* \mathrm{P}<0.05, * * \mathrm{P}<0.01$.

Normal v. children with protein calorie malnutrition

$+\mathrm{P}<0.01$, $\neq \mathrm{P}<0.001$.

\section{Discussion}

Data show that the plasma sulphate uptake ratio is lowered in kwashiorkor. As bioassay of somatomedin involves the stimulation of tissue sulphate uptake in the presence of plasma, the present study may be considered to indicate that plasma somatomedin activity may be lowered in kwashiorkor, an observation in line with that reported by Grant $e$ t al. (1973). Our data also show additionally that the sulphate uptake ratio is not altered in marasmus. The slight increase after treatment indicates that the reduction, if any, is only marginal. Van den Brande and Du Caju (1973) studied somatomedin activity in malnourished children and although they combined the data obtained from marasmic children with those from children with kwashiorkor, it would appear that both groups had low levels of activity. Their data also indicate the probable presence of a somatomedin inhibitor in the plasma of marasmic children. This was not tested in the present series. The normal sulphate uptake observed in marasmic children could probably be taken as evidence against the presence of such an inhibitor. The presence of an inhibitor in kwashiorkor however is not ruled out.

The finding that plasma $\mathrm{GH}$ levels are raised in kwashiorkor but normal in marasmus agrees with our earlier findings (Raghuramulu and Jaya Rao, 1974). There is a consensus regarding the high GH levels in kwashiorkor (Pimstone et al., 1966; Beas et al., 1971; Godard, 1973; Parra et al., 1973; Suskind et al., 1973) but observations on marasmus are discordant (Pimstone et al., 1968; Beas et al., 1971; Godard, 1973; Parra et al., 1973; Suskind et al., 1973). Circulating levels of several proteins known to be synthesised in the liver are markedly lowered in kwashiorkor (Gopalan, 1968). Liver is also one of the sites of somatomedin generation (McConaghey, 1972; Williams and Hughes, 1974). The lowering of somatomedin 
activity in kwashiorkor might therefore be due to its impaired synthesis, as was suggested by Grant $e t$ al. (1973).

It has been suggested that plasma amino-acid levels may determine plasma GH concentration in protein calorie malnutrition (Suskind et al., 1973; Jaya Rao, 1974). The possibility that a decrease in somatomedin feedback, either on the pituitary or on the hypothalamus, could also stimulate excess $\mathbf{G H}$ production needs to be tested. The lack of correlation between the two substances at the outset precludes such a possibility. On the other hand, it was observed that in all children (except one) who had plasma albumin levels below $2 \cdot 5 \mathrm{~g} / 100 \mathrm{ml}(25 \mathrm{~g} / \mathrm{l})$ the sulphate uptake ratio was below 0.7 (Figure). It has earlier been observed that plasma GH levels were raised only when the plasma albumin level fell below this concentration (Raghuramulu and Jaya Rao, 1974). The data of other workers (Pimstone et al., 1968; Samuel and Deshpande, 1972; Lunn et al., 1973) also support the latter observation. The results of the present study indicate that the reduction in sulphate uptake ratio as well as raised plasma $\mathbf{G H}$ levels are observed only below a certain threshold level of plasma albumin. They however, do not indicate whether somatomedin activity could be the primary determinant of the raised plasma GH levels in kwashiorkor.

We thank Dr S. G. Srikantia, Director, for his advice and keen interest. We also thank Drs Vinodini Reddy and C. Bhaskaram for letting us study their patients.

\section{References}

Alford, F. P., Bellair, J. T., Burger, H. G., and Noelle, L. (1972). A simplified assay for somatomedin. Journal of Endocrinology, 54, 365-366.

Beas, F., Contreras, I., Maccioni, A., and Arenas, S. (1971). Growth hormone in infant malnutrition: the arginine test in marasmus and kwashiorkor. British Journal of Nutrition, 26, 169-175.

Daughaday, W. H. (1971). Sulfation factor regulation of skeletal growth. American Journal of Medicine, 50, 277-280.

Godard, C. (1973). Plasma growth hormone levels in severe infantile malnutrition in Bolivia. In Endocrine Aspects of Malnutrition, p. 19. Edited by L. I. Gardner and P. Amacher. Kroc Foundation: California.

Gopalan, C. (1968). Kwashiorkor and marasmus: evolution and distinguishing features. In Calorie Deficiencies and Protein Deficiences, pp. 49-58. Edited by R. A. McCance and E. M. Widdowson. Churchill: London.

Grant, D. B., Hambley, J., Becker, D., and Pimstone, B. L. (1973). Reduced sulphation factor in undernourished children. Archives of Disease in Childhood, 48, 596-600.
Jaya Rao, K. S. (1974). Evolution of kwashiorkor and marasmus. Lancet, 1, 709-711.

Lunn, P. G., Whitehead, R. G., Hay, R. W., and Baker, B. A. (1973). Progressive changes in serum cortisol, insulin, and growth hormone concentrations and their relationship to the distorted amino acid pattern during the development of kwashiorkor. British Journal of Nutrition, 29, 399-422.

McConaghey, P. (1972). The production of sulphation factor by rat liver. Journal of Endocrinology, 52, 1-9.

Parra, A., Garza, C., Garza, Y., Saravia, J. L., Hazlewood, C. F., and Nichols, B. L. (1973). Changes in growth hormone, insulin, and thyroxine values, and in energy metabolism of marasmic infants. Journal of Pediatrics, 82, 133-142.

Pennisi, F. (1968). Fast procedure for radio immunoassay of human growth hormone. Journal of Nuclear Biology and Medicine, 12, 137-138.

Pimstone, B. L., Wittmann, W., Hansen, J. D. L., and Murray, P. (1966). Growth hormone and kwashiorkor. Lancet, 2, 779-780.

Pimstone, B. L., Barbezat, G., Hansen, J. D. L., and Murray, P. (1968). Studies on growth hormone secretion in proteincalorie malnutrition. American Journal of Clinical Nutrition, 21, 482-487.

Raghuramulu, N., and Jaya Rao, K. S. (1974). Growth hormone secretion in protein-calorie malnutrition. Journal of Clinical Endocrinology and Metabolism, 38, 176-180.

Samuel, A. M., and Deshpande, V. R. (1972). Growth hormone levels in protein-calorie malnutrition. Journal of Clinical Endocrinology and Metabolism, 35, 863-867.

Suskind, R., Amatayakul, K., Leitzmann, C., and Olson, R. E. (1973). Interrelationships between growth hormone and amino acid metabolism in protein-calorie malnutrition. In Endocrine Aspects of Malnutrition, p. 99. Edited by L. I. Gardner and P. Amacher. Kroc Foundation: California.

Van den Brande, J. L., and Du Caju, M. V. L. (1973). Plasma somatomedin activity in children with growth disturbances. In Advances in Human Growth Hormone Research, pp. 98126. Edited by S. J. Raiti. DHEW Publication No. (NIH) 74-612. United States Department of Health Education, and Welfare: Washington DC.

Williams, J. P. G., and Hughes, S. (1974). Somatomedin activity from rat livers perfused with human growth hormone. Journal of Endocrinology, 63, 585-586.

Wolfson, W. Q., Cohn, C., Calvary, E., and Ichiba, F. (1948). Studies in serum proteins. V. A rapid procedure for the estimation of total protein, true albumin, true globulin, alpha globulin, beta globulin, and gamma globulin in 1.0 ml serum. American Journal of Clinical Pathology, 18, 723-730.

Yde, H. (1968). A simplified technique for the determination of growth hormone dependent sulphation factor using intact animals. Acta endocrinologica (Copenhagen), 57, $557-564$.

Correspondence to P. S. Mohan, National Institute of Nutrition, Indian Council of Medical Research, Jamai Osmania (PO), Hyderabad 500007 , Andhra Pradesh, India.

Received 28 March 1978 